\title{
Removal of Microorganisms in Drinking Water using a Pulsed High Voltage
}

\author{
Ariadi Hazmi ${ }^{1}$, Reni Desmiarti ${ }^{2,3}$, Eka Putra Waldi ${ }^{1}$ \& Darwison $^{1}$ \\ ${ }^{1}$ Department of Electrical Engineering, Andalas University \\ Kampus Limau Manis, Unand Padang 25163, Indonesia \\ ${ }^{2}$ Department of Chemical Engineering, Bung Hatta University, \\ Jalan Olo Nanggalo No. 19 Padang 25137, Indonesia \\ ${ }^{3}$ Environmental Research Center, Bung Hatta University, \\ Jalan Olo Nanggalo No. 19 Padang 25137, Indonesia \\ E-mail: ariadihazmi@yahoo.com
}

\begin{abstract}
A pulsed high voltage was used to remove microorganisms in drinking water. The effects of the pulsed high voltage on $\mathrm{pH}$, conductivity, temperature and oxidation reduction potential (ORP) of the drinking water were investigated. The observed results show that the removal efficiency with respect to fecal coliforms and total coliforms increased with the increase of the pulsed high voltage. The removal efficiency for microorganisms such as fecal coliforms and total coliforms was in the range $25-100 \%$ and $44-100 \%$, respectively, after the water was exposed to a pulsed high voltage of $5-10 \mathrm{kV}$ for 60 minutes. An increase of the pulsed high voltage caused a decrease in the conductivity and ORP with operational time.
\end{abstract}

Keywords: drinking water; fecal coliforms; pulsed high voltage; total coliforms; water pollutant.

\section{Introduction}

The occurrence of water pollutant contaminants such as microorganisms has been investigated in ground water from Padang City [1]. Ground water is one of the sources of drinking water in Padang City. The presence of microorganisms in particular can have serious consequences, especially for vulnerable members of society such as children or the elderly. Fecal coliforms are a universally used indicator for fecal contamination that has been found to migrate through soil. Conventional water treatment processes, including coagulation/flocculation, sedimentation, filtration and disinfection processes particularly target the removal of colloidal particles from raw water. Such upstream treatment processes prior to disinfection are less effective in removing small-sized water microorganisms.

Many studies have been carried out to investigate the removal of microorganisms from drinking water and surface water using fixed-bed filtration

Received June $6^{\text {th }}, 2012$, Revised December $13^{\text {th }}, 2012$, Accepted for publication January $10^{\text {th }}, 2013$.

Copyright @ 2013 Published by ITB Journal Publisher, ISSN: 2337-5779, DOI: 10.5614/j.eng.technol.sci.2013.45.1.1 
systems [2,3] or membrane filtration [4]. High removal efficiencies (from 99\% to complete removal) can usually be achieved through various mechanisms, such as adsorption and inactivation, depending on filter media characteristics and local climatic conditions. In most cases, removal efficiency tends to increase as the particle deposition gradually increases along the filtration period, due to decreasing filter media porosity and an increase of the specific surface area for adsorption, until breakthrough of the deposited particles from the filter takes place.

Non-thermal plasma generated in electrical discharges in a liquid, or at the gasliquid interface, leads to the formation of oxidizing species, both radicals $\left(\mathrm{H}^{+}\right.$, $\left.\mathrm{O}^{-2}, \mathrm{OH}^{-}\right)$and molecules $\left(\mathrm{H}_{2} \mathrm{O}_{2}, \mathrm{O}_{3}\right.$, etc. $)$ [5], that are effective for the removal of organic pollutants. Krause et al. [6] used a corona discharge over water in order to remove micropollutants and obtained almost $100 \%$ conversion after a 30 minute plasma treatment with a power of $500 \mathrm{~W}$ introduced in the plasma. Gerrity, et al. [7] have suggested that non-thermal plasma may be a viable alternative advanced oxidation process (AOP) due to its comparable energy requirements for water pollutants degradation and its ability to operate without any additional feed chemicals.

For their investigation of pulsed discharge plasma for treating pollutants in water, Clements, et al. [8] used a discharge system with needle-to-plate electrodes in order to study the relation between the generation of streamer discharge, spread length of streamer, varieties of active species, pulse polarity and solution conductivity. Sato, et al. [9] have investigated the influence of solution conductivity and discharge energy on the production of active species $\left(\mathrm{OH}^{-}, \mathrm{H}_{2} \mathrm{O}_{2}\right)$ in a needle-to-plate electrode reactor used to kill microorganisms. Sugiarto [10] obtained the degradation efficiency of organic pollutants in water in different discharge states of a needle-to-plate electrode system. Li, et al. [11] also reported that the degradation efficiency of phenol in water increased with the increase of the pulsed peak voltage and treatment time. Although these discharge plasma reactor systems have a higher removal efficiency for organic pollutants, there are still many problems that need to be investigated before industrialized application of pulsed discharge plasma in wastewater treatment/disposal can be realized, such as the oxidation of discharge affecting the removal efficiency of microorganisms.

\section{Materials and Methods}

\subsection{Source of Water}

Desmiarti, et al. [1] have investigated three water samples from ground water around Kuranji. They found that the water contained a high level of 
microorganisms. Accordingly, water samples were collected from one of the ground water sources in Kuranji Padang, West Sumatra, Indonesia. The samples were taken three times, transported to the laboratory and used directly for the experiments. The water quality is displayed in Table 1.

Table 1 Characteristics of water samples from ground water.

\begin{tabular}{llc}
\hline \multicolumn{1}{c}{ Parameter } & \multicolumn{1}{c}{ Unit } & Value \\
\hline $\mathrm{pH}^{*}$ & & $6.2 \pm 0.1$ \\
Conductivity* & $\mu \mathrm{S} / \mathrm{cm}$ & $135 \pm 2$ \\
Temperature* & ${ }^{\circ} \mathrm{C}$ & $26.9 \pm 6.1$ \\
ORP $^{*}$ & $\mathrm{mV}$ & $213 \pm 1.7$ \\
Iron $(\mathrm{Fe})^{* *}$ & $\mathrm{mg} / \mathrm{L}$ & 0.129 \\
Manganese $(\mathrm{Mn})^{* *}$ & $\mathrm{mg} / \mathrm{L}$ & 0.12 \\
Phenol** & $\mathrm{mg} / \mathrm{L}$ & $<0.0005$ \\
Turbidity** & $\mathrm{NTU}$ & 1.5 \\
Fecal Coliforms** & $\mathrm{MPN} / 100 \mathrm{~mL}$ & 12 \\
Total Coliforms** & $\mathrm{MPN} / 100 \mathrm{~mL}$ & 27 \\
\hline
\end{tabular}

$*$ The measured values for three water samples are given in the form of the
mean value \pm the standard deviation.
** The measured values for three samples

\subsection{Experimental Setup}

The schematic diagram of the experimental system for removal of microorganisms with a pulsed high voltage is illustrated in Figure 1. A stationer spark gap was used to generate the pulsed high voltage. The pulsed streamer discharge occurs between the needle-plane electrodes, where a pulsed high

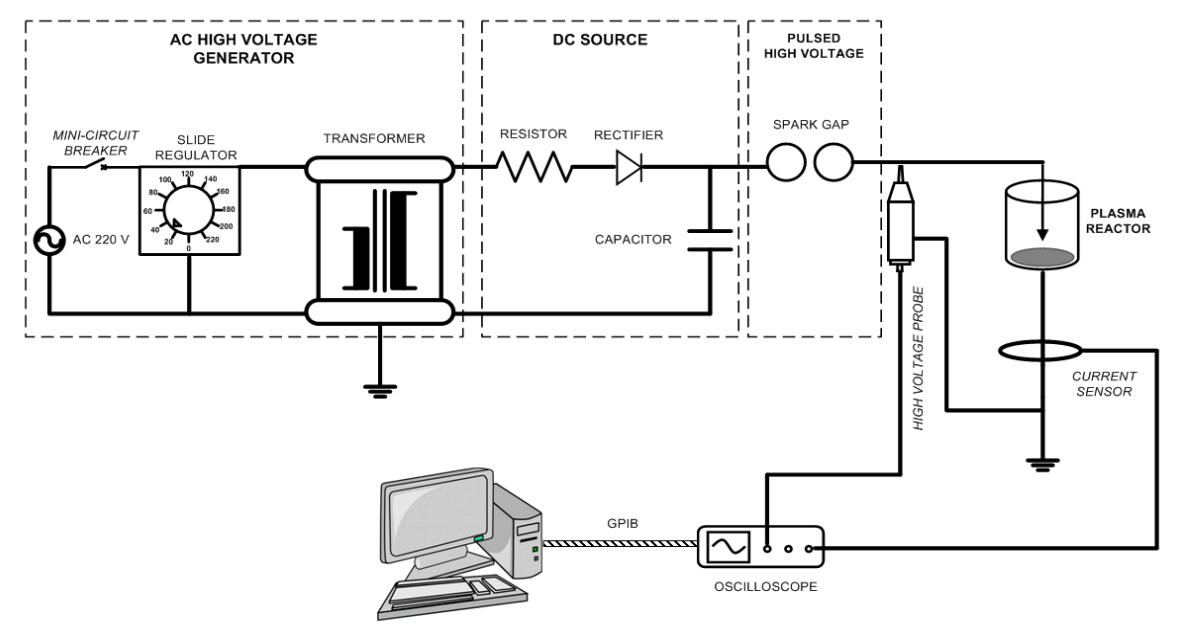

Figure 1 Schematic diagram of experimental system. 
voltage is applied to the needle electrode. The plasma reactor was made of Plexiglas having an inner diameter and height of $10.4 \mathrm{~cm}$ and $8 \mathrm{~cm}$, respectively. The needle-to-plane electrode system was used with a separation distance of $7 \mathrm{~mm}$. The needle electrode was made of $1 \mathrm{~mm}$ diameter stainless steel and the plane electrode was made of $10.4 \mathrm{~mm}$ diameter stainless steel. The volume of the water sample in the reactor was $500 \mathrm{~mL}$.

\subsection{Measurement Methods}

Fecal coliform and total coliforms were analyzed by most probable number (MPN) using five multiple tubes, the number of coliforms expressed as MPN/100 mL (APHA, 2005). In addition, ORP, $\mathrm{pH}$ and conductivity were analyzed using an ORP meter (HI 98120), pH meter (HI 98107) and conductivity meter (HI 98303), respectively, by Hanna.

\section{Result and Discussion}

\subsection{Discharge Characteristics}

A pulsed high voltage generator with spark gap was used. The pulsed high voltage was formed using a capacitor $1.2 \mathrm{nF}, 50 \mathrm{~Hz}, 5-10 \mathrm{kV}$. The pulsed high voltage and current were measured using an oscilloscope (PicoScope 4424) with a high voltage probe (Textronix P6015A) and Rogowski coil, respectively.
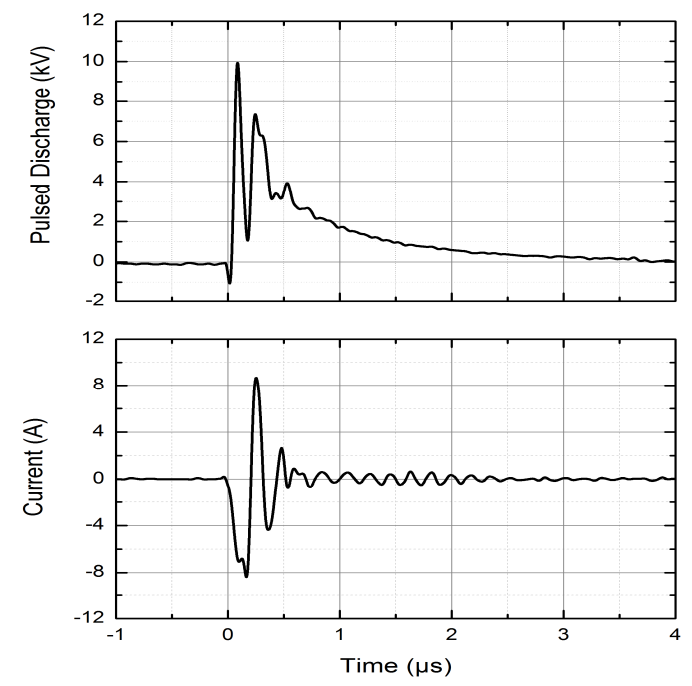

Figure 2 Waveform of the pulsed high voltage and current.

The typical waveforms of the pulsed high voltage and current in the plasma reactor are shown in Figure 2. The waveforms have a rise time of several 
nanoseconds. The pulsed high voltage generated discharged enough energy to produce active species $\left(\mathrm{OH}^{-}, \mathrm{H}_{2} \mathrm{O}_{2}\right)$ that killed microorganisms in the plasma reactor.

\subsection{Profile of pH, Conductivity, Temperature and ORP}

In order to investigate the use of pulsed discharge plasma for the removal of microorganisms, the effects of the pulsed high voltage supplied to the plasma reactor on $\mathrm{pH}$, conductivity, ORP and temperature of the water sample were investigated as shown in Figure 3. The effect of the pulsed high voltage on $\mathrm{pH}$ is shown in Figure 3(a). This figure shows that the pulsed high voltage had little effect on the $\mathrm{pH}$ value of the water $(0.1-0.2)$. A higher $\mathrm{pH}$ solution is favorable for producing $\mathrm{H}_{2} \mathrm{O}_{2}$, and $\mathrm{H}_{2} \mathrm{O}_{2}$ can improve the removal efficiency of microorganisms. The results obtained in these experiments show that the $\mathrm{pH}$ tended to be relatively more basic after the pulsed high voltage was applied to the plasma reactor. This makes the system suitable for the removal of microorganisms in the water, as supported by $\mathrm{Li}$, et al. [11]. Future studies are needed to study the effects of $\mathrm{pH}$ on the removal of microorganisms.
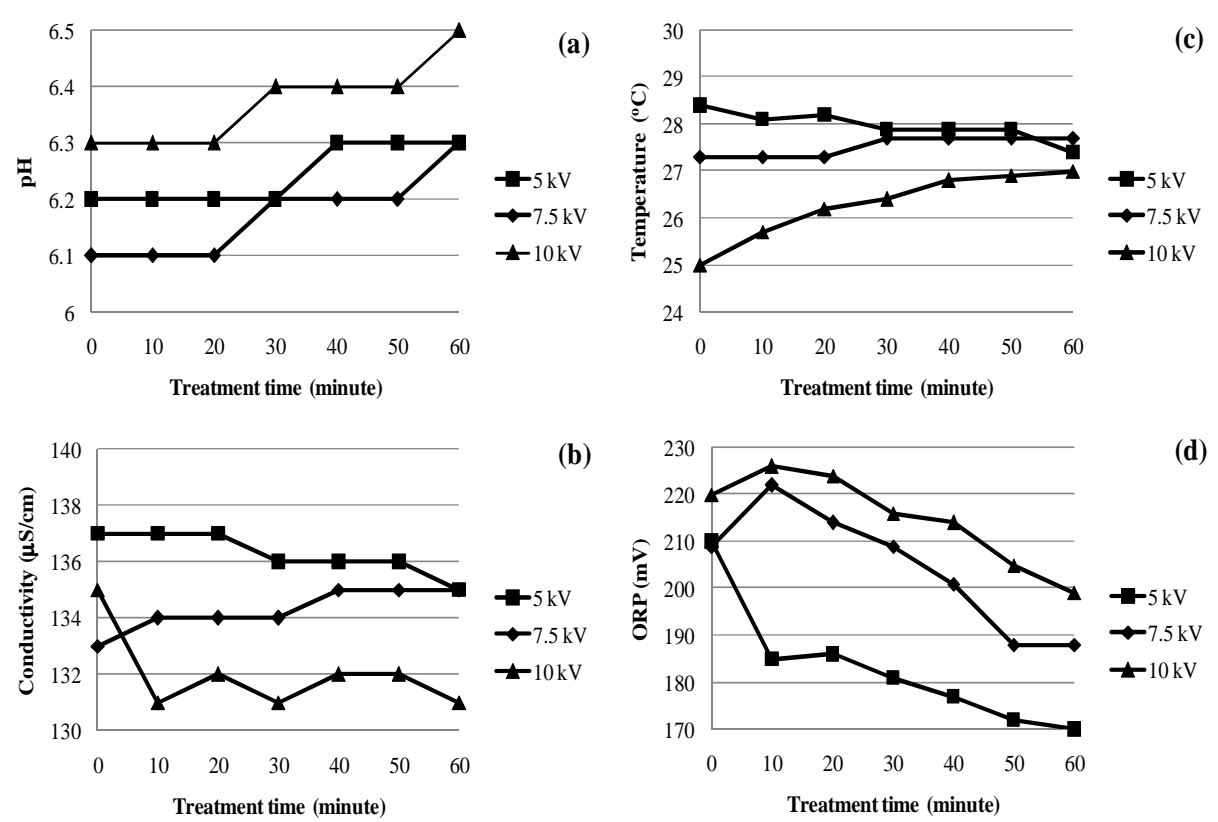

Figure 3 Time profiles of $\mathrm{pH}$, conductivity, temperature and ORP in the plasma reactor during the experiments.

Conductivity is an easy and quick way to detect changes in the total ion content. The trend of conductivity with treatment time, by changing the pulsed peak 
voltage injected into the reactor, is shown in Figure 3(b). The conductivity decreased with slight changes in the pulsed high voltage. The average conductivity was $136.3,134.3$ and $132 \mu \mathrm{S} / \mathrm{cm}$ for a pulsed high voltage of $5,7.5$ and $10 \mathrm{kV}$, respectively. Due to the differing initial temperature it was different for each run. The average temperature was $28,27.5$ and $26.3{ }^{\circ} \mathrm{C}$ for a pulsed high voltage of $5,7.5$ and $10 \mathrm{kV}$, respectively. Because of the occurrence of a temperature rise at a voltage of $10 \mathrm{kV}$ (see Figure 3(c)), the system encourages mineral salts to attach themselves to the electrodes. This led to scale formation on the surface of the electrode.

In addition, ORP was typically measured to determine the oxidizing or reducing potential of the water samples. This indicates possible contamination, especially by industrial wastewater. As displayed in Figure 3(d), the ORP decreased with time after running for 60 minutes. The average ORP was 183, 204.4, 214.9 for a pulsed high voltage of $5,7.5$ and $10 \mathrm{kV}$, respectively. Comparing the ORP with the initial conditions $(213 \mathrm{mV})$, there were slightly changes, especially for $10 \mathrm{kV}$. However, it is clearly seen that the values tended to decrease with operational time as compared to 0 minutes, with a low $\mathrm{kV}$ having a very strong effect on lowering the ORP, as shown in Figure 3(d).

\subsection{Removal of Microorganisms}

Figure 4 shows the removal efficiency of microorganisms of the experimental system. The results indicate that removal efficiency increased by enhancing the pulsed high voltage supplied into the reactor after running for 60 minutes. Removal efficiency of microorganisms as fecal coliforms was 25, 58 and $100 \%$ for pulsed high voltages of $5,7.5$ and $10 \mathrm{kV}$, respectively. The removal efficiency of microorganisms as total coliforms was 44,48 and $100 \%$ for pulsed high voltages of $5,7.5$ and $10 \mathrm{kV}$, respectively.

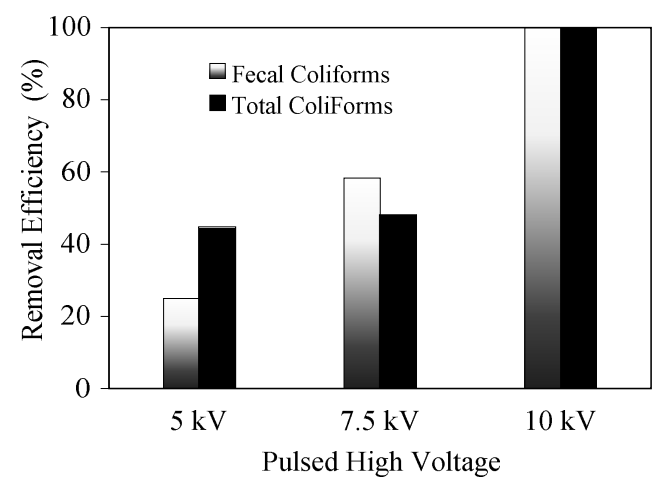

Figure 4 Effect of pulsed high voltage on removal efficiency of microorganisms. 


\section{Conclusion}

Microorganisms in water were removed effectively by a pulsed high voltage plasma system. The obtained results show that the $\mathrm{pH}$ of the drinking water produced was in the range 6.2-6.4. Increasing the pulsed high voltage caused a decrease in the conductivity and ORP with operational time. A pulsed high voltage of $5-10 \mathrm{kV}$ supplied to the water for 60 minutes showed a removal efficiency for fecal coliforms and total coliforms in the range of $25-100 \%$ and $44-100 \%$, respectively.

\section{Acknowledgements}

The authors would like to thank the Directorate General of Higher Education, Ministry of National Education for supporting this work (Fundamental research, grand number 169/SP2H/Dit.Litabmas/IV/2011). The authors also thank to our students Rizki, Randy, Bayu, Lilla and Dedi for making this work possible.

\section{References}

[1] Desmiarti, R., Ellyta, S., Fadilla, H. \& Laila, F., Ground Water and Surface Water Quality in Campus II Bung Hatta University Padang, Proceeding KonNas PBKL-2010, ISSN: 2087-6343, pp. 50-55, Padang 45 November 2010.

[2] Devi, R., Alemayehu, E., Singh, V., Kumar, A. \& Mengistie, E., Removal of Fluoride, Arsenic and Coliform Bacteria by Modified Homemade Filter Media from Drinking Water, Bioresource Technology, 99, pp. 2269-2274, 2008.

[3] Aronino, R., Dlugy, C., Arkhangelsky, E., Shandalov, S., Oron, G., Brenner, A. \& Gitis, V., Removal of Viruses from Surface Water and Secondary Effluents by Sand Filtration, Water Research, 43, pp. 87-96, 2009.

[4] Chiemchaisri, W., Dumrongsukit, C., Threedeach, S., Ngo, H.H. \& Vigneswaran, S., Removal of Water-Borne Microorganisms in Floating Media Filter-Microfiltration System for Water Treatment, Bioresource Technology, 102, pp. 3407-3416, 2011.

[5] Lukes, P., Clupek, M., Sunka, P., Peterka, F., Sano, T., Negishi, N., Matsuzawa, S. \& Takeuchi, K., Degradation of Phenol by Underwater Pulsed Corona Discharge in Combination with $\mathrm{TiO}_{2}$ photocatalysis, Res ChemIntermed, 31, pp. 285-294, 2005.

[6] Krause, H., Schweiger, B., Schuhmacher, J., Scholl, S. \& Steinfeld, U., Degradation of the Endocrine Disrupting Chemicals (EDCs) Carbamazepine, Clofibric Acid, and Iopromide by Corona Discharge Over Water, Chemosphere, 75, pp. 163-168, 2009. 
[7] Gerrity, D., Stanford, B.D., Trenholm, R.A. \& Snyder, S.A., An Evaluation of A Pilot-Scale Non Thermal Plasma Advanced Oxidation Process For Trace Organic Compound Degradation, Water Research, 44, pp. 493-504, 2010.

[8] Clements, J.S., Sato, M. \& Davis, R.H., Preliminary Investigation of Prebreakdown and Chemical Reaction Using a Pulsed High Voltage on Industrial Application, 1A-23(2), 1987.

[9] Sato, M., Soutome, T., Mii, S., Ohshima, T. \& Yamada, Y., Decomposition of Phenol in Water Using Water Surface Plasma In Wetted-Wall Reactor, International Journal of Plasma Environmental Science \& Technology, 1, pp. 71-75, 2007.

[10] Sugiarto, A.T., Electrical Discharge (Plasma) dalam Air, Widya Riset, 2003.

[11] Li, J., Sato, M. \& Ohshima, T., Degradation of Phenol in Water Using A Gas-Liquid Phase Pulsed Discharge Plasma Reactor, Thin Solid Film, 515, pp. 4283-4288, 2007. 